\title{
The single-particle mixing state and cloud scavenging of black carbon: a case study at a high-altitude mountain site in southern China
}

\author{
Guohua Zhang ${ }^{1}$, Qinhao Lin ${ }^{1,2}$, Long Peng ${ }^{1,2}$, Xinhui Bi ${ }^{1}$, Duohong Chen $^{3}$, Mei Li ${ }^{4,5}$, Lei Li ${ }^{4,5}$, Fred J. Brechtel ${ }^{6}$, \\ Jianxin Chen ${ }^{7}$, Weijun Yan ${ }^{7}$, Xinming Wang ${ }^{1}$, Ping'an Peng ${ }^{1}$, Guoying Sheng ${ }^{1}$, and Zhen Zhou ${ }^{4,5}$ \\ ${ }^{1}$ State Key Laboratory of Organic Geochemistry and Guangdong Key Laboratory of Environmental Resources Utilization \\ and Protection, Guangzhou Institute of Geochemistry, Chinese Academy of Sciences, Guangzhou 510640, PR China \\ ${ }^{2}$ University of Chinese Academy of Sciences, Beijing 100039, PR China \\ ${ }^{3}$ State Environmental Protection Key Laboratory of Regional Air Quality Monitoring, Guangdong Environmental \\ Monitoring Center, Guangzhou 510308, PR China \\ ${ }^{4}$ Institute of Mass Spectrometer and Atmospheric Environment, Jinan University, Guangzhou 510632, PR China \\ ${ }^{5}$ Guangdong Engineering Research Center for Online Atmospheric Pollution Source Apportionment, \\ Guangzhou 510632, PR China \\ ${ }^{6}$ Brechtel Manufacturing Inc., Hayward, 94544, CA, USA \\ ${ }^{7}$ Shaoguan Environmental Monitoring Center, Shaoguan 512026, PR China
}

Correspondence: Xinhui Bi (bixh@gig.ac.cn)

Received: 23 August 2017 - Discussion started: 25 August 2017

Revised: 15 November 2017 - Accepted: 16 November 2017 - Published: 19 December 2017

\begin{abstract}
In the present study, a ground-based counterflow virtual impactor (GCVI) was used to sample cloud droplet residual (cloud RES) particles, while a parallel $\mathrm{PM}_{2.5}$ inlet was used to sample cloud-free or cloud interstitial (cloud INT) particles. The mixing state of black carbon (BC)-containing particles and the mass concentrations of $\mathrm{BC}$ in the cloud-free, RES and INT particles were investigated using a single-particle aerosol mass spectrometer (SPAMS) and two aethalometers, respectively, at a mountain site (1690 ma.s.l.) in southern China. The measured BCcontaining particles were extensively internally mixed with sulfate and were scavenged into cloud droplets (with number fractions of $0.05-0.45$ ) to a similar (or slightly lower) extent as all the measured particles (0.07-0.6) over the measured size range of $0.1-1.6 \mu \mathrm{m}$. The results indicate the preferential activation of larger particles and/or that the production of secondary compositions shifts the BC-containing particles towards larger sizes. BC-containing particles with an abundance of both sulfate and organics were scavenged less than those with sulfate but limited organics, implying the importance of the mixing state on the incorporation of BCcontaining particles into cloud droplets. The mass scaveng-
\end{abstract}

ing efficiency of $\mathrm{BC}$ with an average of $33 \%$ was similar for different cloud events independent of the air mass. This is the first time that both the mixing state and cloud scavenging of BC in China have been reported. Our results would improve the knowledge on the concentration, mixing state, and cloud scavenging of $\mathrm{BC}$ in the free troposphere.

\section{Introduction}

Black carbon (BC), also known as soot or elemental carbon, is primarily emitted from incomplete combustion processes (Bond et al., 2013; Petzold et al., 2013). Fresh BC-containing particles are generally hydrophilic due to the presence of thin coatings of inorganic or organic materials (Zuberi et al., 2005), and during transport they become more hydrophilic when further coated through coagulation, condensation, and photochemical oxidation (Zuberi et al., 2005; Zaveri et al., 2010; Matsui, 2016). Hydrophilic BC-containing particles can act as cloud condensation nuclei $(\mathrm{CCN})$ and thus modify cloud microphysical properties (Straub et al., 2012; Schroder 
et al., 2015; Roth et al., 2016). The increase in CCN activity enhances the in-cloud scavenging of $\mathrm{BC}$ and thus reduces its lifetime (Zaveri et al., 2010). Aerosol-cloud interactions represent one of the largest uncertainties in our current understanding of human-induced climate forcing (McFiggans et al., 2006; Andreae and Rosenfeld, 2008). Therefore, a more comprehensive understanding of how aerosol particles form cloud droplets is required in order to reduce the uncertainty of the impacts of aerosols on the climate (Furutani et al., 2008).

The abilities of particles to act as CCN are largely controlled by their sizes and chemical compositions or mixing state (Dusek et al., 2006; Cubison et al., 2008; Kammermann et al., 2010; Baustian et al., 2012; Ching et al., 2012). Larger aerosol particles were found to be more easily scavenged into cloud droplets (Drewnick et al., 2007). Zhou et al. (2009) found higher scavenging rates for sulfate, nitrate, and $\mathrm{BC}$ than those for organics at Mount Tai in northern China. At the same site, $92 \%$ of the cloud residual particles were attributed to sulfate-related salts ( $\mathrm{Li}$ et al., 2011a). In contrast, the chemical compositions of the original $\mathrm{CCN}$ could be altered after the evaporation of the cloud droplets through the effective formation of secondary aerosol compositions during cloud processing (Hayden et al., 2008; Herrmann et al., 2015; Roth et al., 2016). The mixing state of BC-containing particles is of great concern because their activation as $\mathrm{CCN}$ is primarily attributed to the presence of secondary coatings (Lambe et al., 2015; Schroder et al., 2015). Additionally, the mixing state of BC-containing particles is complex and constantly changing in the atmosphere and is highly influenced by particle size, sources, the formation of secondary species, and transport processes (Cahill et al., 2012; Healy et al., 2012; Zhang et al., 2014).

Recent in situ studies of cloud droplets have provided the most direct information on the incorporation of $\mathrm{BC}$ into clouds. The mass scavenging efficiency was observed to be in a range of $33-74 \%$ for $\mathrm{BC}$, which was higher with increasing particle sizes at the Puy de Dôme (1465 ma.s.l.), France (Sellegri et al., 2003). It ranged from 13 to $50 \%$, corresponding to different air masses at a coastal Chilean hill (450 m a.s.1.) (Heintzenberg et al., 2016). Cozic et al. (2007) reported a scavenging rate of $\mathrm{BC}$ similar to those of bulk aerosols due to its internal mixing state with soluble materials. Wang et al. (2012) showed a higher scavenging efficiency for BC than those for organics. Roth et al. (2016) found an enhanced contribution of BC-containing particles in cloud residual particles compared to that in interstitial particles. However, Zelenyuk et al. (2010) observed negligible BC in cloud droplet residual particles above Alaska, USA. Therefore, an in-depth study on the composition, size, and mixing state of BC in cloud droplets and interstitial particles is necessary for a better understanding of the interactions between $\mathrm{BC}$ and cloud droplets and the influences of anthropogenic emissions on cloud formation in the free troposphere.
Single-particle mass spectrometry (SPMS) studies on fog interstitial particles and droplet residual particles were performed previously at an urban site in southern China (Zhang et al., 2012; Bi et al., 2016). The predominance of BCcontaining particles serving as effective fog condensation nuclei highlights the important influence of anthropogenic emissions on the public environment and regional climate (Bi et al., 2016). However, there is no direct observation of the cloud scavenging of $\mathrm{BC}$ or the mixing states of cloud interstitial (cloud INT) and droplet residual (cloud RES) BCcontaining particles in the high-altitude atmosphere or the free troposphere above China to date. Therefore, the sizeresolved mixing state and the scavenging efficiency of BCcontaining particles were investigated at a high-altitude site to further our knowledge of (1) the mixing state of BCcontaining particles, (2) the influence of the mixing state on the incorporation of BC into cloud droplets, and (3) the influence of anthropogenic activities on cloud formation in the free troposphere above southern China.

\section{Methods}

\subsection{Sampling setup}

The observations of cloud events were conducted at the National Atmospheric Background Monitoring Station in Nanling of Guangdong Province, which is located on the top of Mount Tianjing $\left(24^{\circ} 41^{\prime} 56^{\prime \prime} \mathrm{N}, 112^{\circ} 53^{\prime} 56^{\prime \prime} \mathrm{E} ; 1690 \mathrm{~m}\right.$ a.s.1.) in southern China, from 16 to 26 January 2016. The average boundary layer height (https://www.arl.noaa.gov) at the site over the study is $\sim 280 \mathrm{~m}$ and the surrounding ground altitude is $\sim 500 \mathrm{~m}$ for this region. It is reasonable to consider this site sampling free-tropospheric air throughout the study. The site is located in a natural preserve distant from anthropogenic activities. A map of the location and terrain of the site can be found elsewhere (Lin et al., 2017).

Aerosols were introduced into the instruments through two parallel sampling lines. The first inlet is a ground-based counterflow virtual impactor (GCVI) (model 1205, Brechtel Mfg., Inc., USA) (Bi et al., 2016). The GCVI employs a compact wind tunnel upstream of the CVI inlet (model 1204) to accelerate fog and cloud droplets into the CVI inlet tip. Similar methodologies have been extensively applied to collect fog and cloud RES particles (e.g., Sorooshian et al., 2013; Roth et al., 2016; van Pinxteren et al., 2016). The detail information on the design of the CVI inlet and testing on the sizeresolved transmission efficiency of droplets can be found elsewhere (Shingler et al., 2012). The inlet cut size was set to be $8 \mu \mathrm{m}$, at which the transmission efficiency of droplets is $50 \%$. The enhancement factor (EF) was calculated according to the equation (Shingler et al., 2012) $\mathrm{EF}=A_{\text {tip }} \cdot V_{\text {air }} / q_{\text {sample }}$, where $A_{\text {tip }}$ is the area of the inlet tip where drops enter, $V_{\text {air }}$ is wind tunnel velocity, and $q_{\text {sample }}$ is the volumetric flow rate of sampled air in the CVI inlet. $A_{\text {tip }}$ is $1.67 \times 10^{-5} \mathrm{~m}^{2}, q_{\text {sample }}$ 
is $151 \mathrm{~min}^{-1}$, and $V_{\text {air }}$ was set to $\sim 80 \mathrm{~m} \mathrm{~s}^{-1}$, coinciding with an EF of 5.25. Therefore, the reported mass concentrations for the cloud RES particles in the following text were first divided by 5.25 . The sampled cloud droplets enter the evaporation chamber (with an airflow temperature of $40^{\circ} \mathrm{C}$ ), where the droplets are dried, thereby leaving behind cloud RES particles that were $\mathrm{CCN}$. The influence of background particles on the collection of the cloud RES particles could be negligible. A test on the cloud-free air showed that the average particles number concentration sampled by the GCVI was $\sim 1 \mathrm{~cm}^{-3}$, far below the level $\left(\sim 2000 \mathrm{~cm}^{-3}\right)$ air over the study (Zhang et al., 2017). A testing before measurements demonstrates that the influence of background aerosols on the collection of cloud droplets could be negligible (Zhang et al., 2017). The ambient inlet is a $\mathrm{PM}_{2.5}$ sampling line that delivers ambient particles during cloud-free periods or cloud INT particles during cloud events. Cloud INT particles were regarded as $\mathrm{PM}_{2.5}$ during the cloud events. More detailed description on the sampling can be found in the companion papers (Lin et al., 2017; Zhang et al., 2017).

Cloud events were characterized by a sudden drop in visibility and a sharp increase in the relative humidity $(\mathrm{RH})$ measured by the GCVI. An upper-limit visibility threshold of $5 \mathrm{~km}$ and a lower-limit RH threshold of $95 \%$ were established to identify the cloud events and trigger the sampling of the cloud RES particles.

An illustrative scheme of the instrumentation setup is provided in Fig. S1 in the Supplement. Downstream of the GCVI, an aethalometer (model AE-33, Magee Scientific, USA), a single-particle aerosol mass spectrometer (SPAMS, Hexin Analytical Instrument Co., Ltd.), and a scanning mobility particle sizer (SMPS, MSP Corporation, USA) were used to measure the concentration of $\mathrm{BC}$, the sizeresolved mixing state of the collected particles, and the number size distribution of submicron particles, respectively. Downstream of the ambient inlet, an SMPS (Grimm 5.041, Germany), an aethalometer (model AE-31, Magee Scientific, USA), and a tapered element oscillating microbalance (model 1405, Thermo Scientific, USA) were used to determine the number size distribution of submicron particles and the mass concentrations of $\mathrm{BC}$ and $\mathrm{PM}_{2.5}$, respectively. During the cloud-free periods, the instruments downstream of the GCVI were manually shifted and connected to the ambient $\mathrm{PM}_{2.5}$ inlet. During the present study, three cloud events (clouds I, II, III, each with a RH constantly above $95 \%$ for more than $12 \mathrm{~h}$ ) were encountered and identified by the GCVI (Lin et al., 2017), as shown in Fig. 1. During clouds I and II, the cloud RES particles provided by the GCVI were measured by the instruments downstream of the GCVI. During cloud III, the cloud RES and cloud INT particles were intermittently measured by these instruments at approximately 1-hour intervals.

\subsection{Determinations of the mass concentrations of $\mathrm{BC}$}

The AE-31 and AE-33 measured the BC concentration at the wavelength of $880 \mathrm{~nm}$, which is typically represented as equivalent BC (EBC) (Petzold et al., 2013). The EBC concentration reported in the present study was measured using the AE-33 described in great detail elsewhere (Drinovec et al., 2015). The limitations and uncertainties of the AE31 in measuring BC and the necessary corrections were well documented (Weingartner et al., 2003; Arnott et al., 2005; Backman et al., 2016). A brief description of this issue is provided in the Supplement.

\subsection{Identification of BC-containing particles by the SPAMS}

Both the vacuum aerodynamic diameter $\left(d_{\mathrm{va}}\right)$ and the chemical compositions of the individual particles were analyzed by the SPAMS, as briefly described in the Supplement. A detailed description of the performance and the calibrations of the SPAMS can be found elsewhere (L. Li et al., 2011). The mass spectra for $\sim 75000$ particles with $d_{\mathrm{va}}$ values in the range of $0.1-1.6 \mu \mathrm{m}$ were obtained by the SPAMS over the study. The diameter is represented herein as $d_{\mathrm{va}}$ rather than the equivalent volume diameter $\left(d_{\mathrm{ve}}\right)$, the conversion for which can be found in the Supplement (DeCarlo et al., 2004; $\mathrm{Hu}$ et al., 2012). An adaptive-resonance-theory-based neural network algorithm (ART-2a) was applied to cluster the individual particles based on the presence and intensities of ion peaks (Song et al., 1999) with a vigilance factor of 0.7 , a learning rate of 0.05 , and 20 iterations. Three BC particle types were obtained: the mass spectra of particles with more carbon cluster ions $\left(\mathrm{C}_{\mathrm{n}}^{ \pm}, n>6\right)$ and sulfate (BC-sul1), those with fewer carbon cluster ions $\left(\mathrm{C}_{\mathrm{n}}^{ \pm}, n \leq 6\right)$ and more intense sulfate (BC-sul2), and those with an abundance of both sulfate and organics (BC-OC-sul). The relative amount of OC to $\mathrm{BC}$ for the $\mathrm{BC}-\mathrm{OC}$-sul particles is significantly larger than that in the BC-sul1 and $\mathrm{BC}$-sul2 particles, as indicated in Fig. S2. Over all of the detected BC-containing particles, the BC-sul2 type is the most abundant $(63 \%)$ particle type, followed by the BC-sul1 (21\%) and BC-OC-sul (16\%) types. More detailed information regarding the other particle types can be found elsewhere (Lin et al., 2017).

\section{Results and discussion}

During the sampling periods, the temperature and $\mathrm{RH}$ generally varied between -9.9 and $-11.4{ }^{\circ} \mathrm{C}$ and between 6.7 and $100 \%$, respectively. The sampling durations for the cloudfree, cloud RES, and cloud INT (only detected in cloud III) particles were approximately 109, 123, and $26 \mathrm{~h}$, respectively. The detected numbers of the cloud-free, cloud RES, and cloud INT particles by the SPAMS were 48 835, 23616 , and 1063, respectively. The average number fractions of BCcontaining particles in the cloud-free, cloud RES, and cloud 


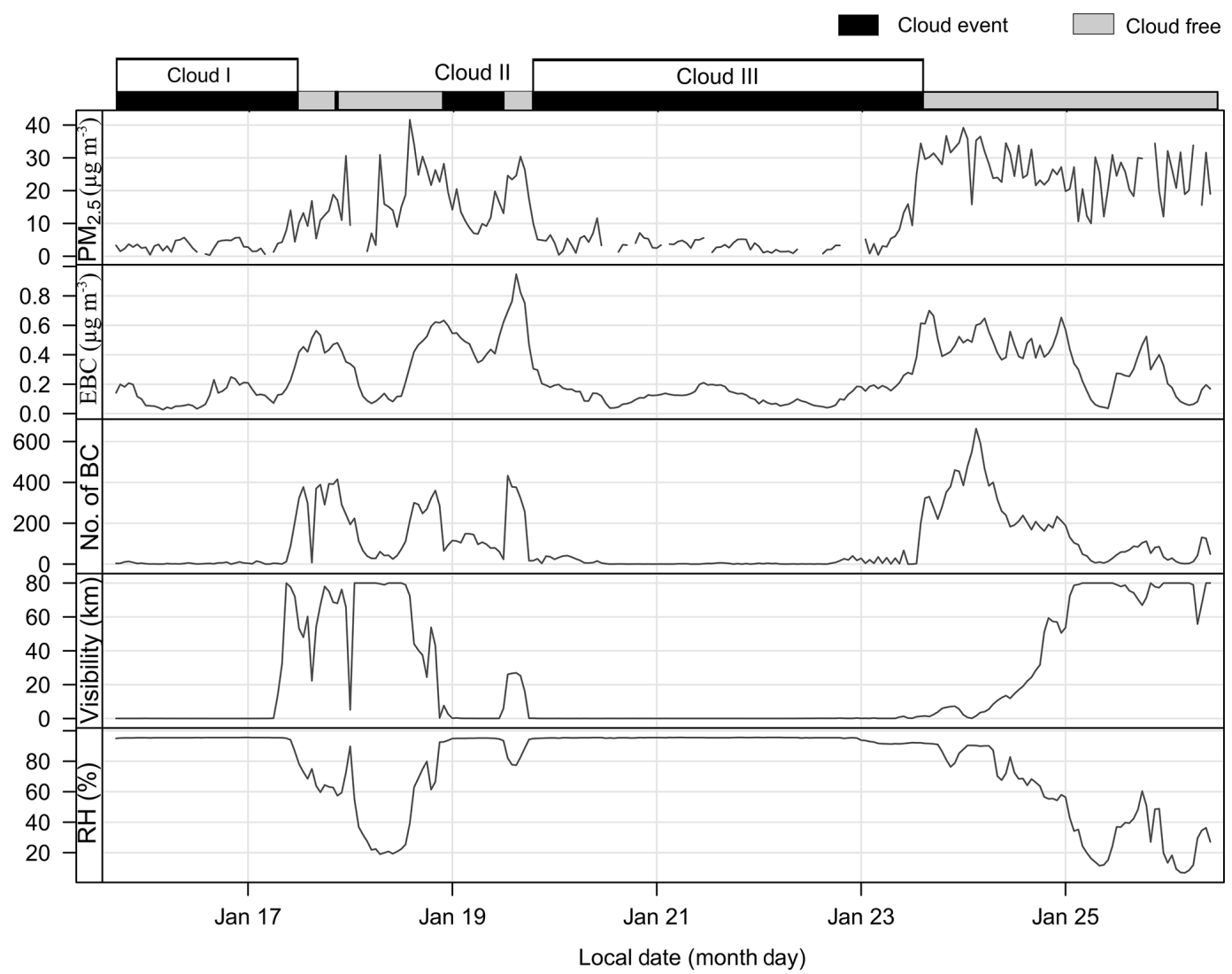

Figure 1. Temporal profiles (in $1 \mathrm{~h}$ resolution) of $\mathrm{PM}_{2.5}$, EBC mass concentrations, number of BC-containing particles by SPAMS, RH, and visibility. Three cloud events are illustrated with black bars above the figure. $\mathrm{PM}_{2.5}$ during the cloud events corresponded to the cloud INT particles. EBC and number of BC-containing particles data were shown for all categories, including the cloud-free, cloud RES, and cloud INT particles. The cloud INT particles were only measured during cloud III.
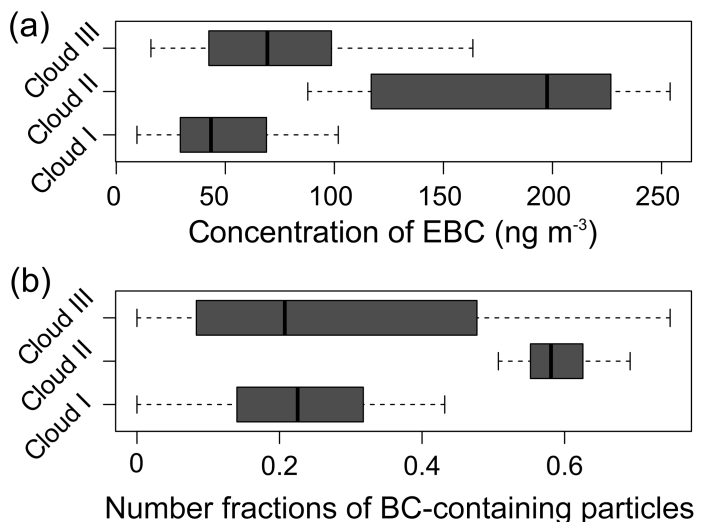

Figure 2. Box and whisker plots of (a) concentration of EBC and (b) number fraction of BC-containing particles for each cloud event. In a box and whisker plot, the lower, median, and upper lines of the box denote the 25th, 50th, and 75th percentiles, respectively, and the lower and upper edges of the whisker denote the 10th and 90th percentiles, respectively.
INT particles were 44,49 , and $53 \%$, respectively. The number fractions of BC-containing particles that were incorporated within the cloud droplets ranged between those observed at an urban site $(70 \%)$ in southern China (Bi et al., 2016) and those observed at a mountain site $(\sim 30 \%)$ in Germany (Roth et al., 2016). While some mineral dust might trigger heterogeneous ice nucleation at temperatures below $-7^{\circ} \mathrm{C}$ (Atkinson et al., 2013), this would not influence the discussion on the number fraction and chemistry of the cloud RES BC-containing particles. The cloud RES BC-containing particles only accounted for $\sim 0.1 \%$ of all the detected ones in a $2 \mathrm{~h}$ window when the average temperature was $\sim-7^{\circ} \mathrm{C}$.

Air masses from the southwestern continental and marine areas dominated throughout the sampling period, carrying relatively warmer and wetter air masses that benefited the formation of clouds based on the back-trajectory analysis (Lin et al., 2017). Cloud II was strongly influenced by a northeastern air mass in contrast to the southwestern air mass that dominated during cloud I and III. As shown in Fig. 2, the air mass during cloud II represents relatively polluted conditions. The mass concentration of EBC during cloud II was approximately $200 \mathrm{ng} \mathrm{m}^{-3}$, which is 4 times that 

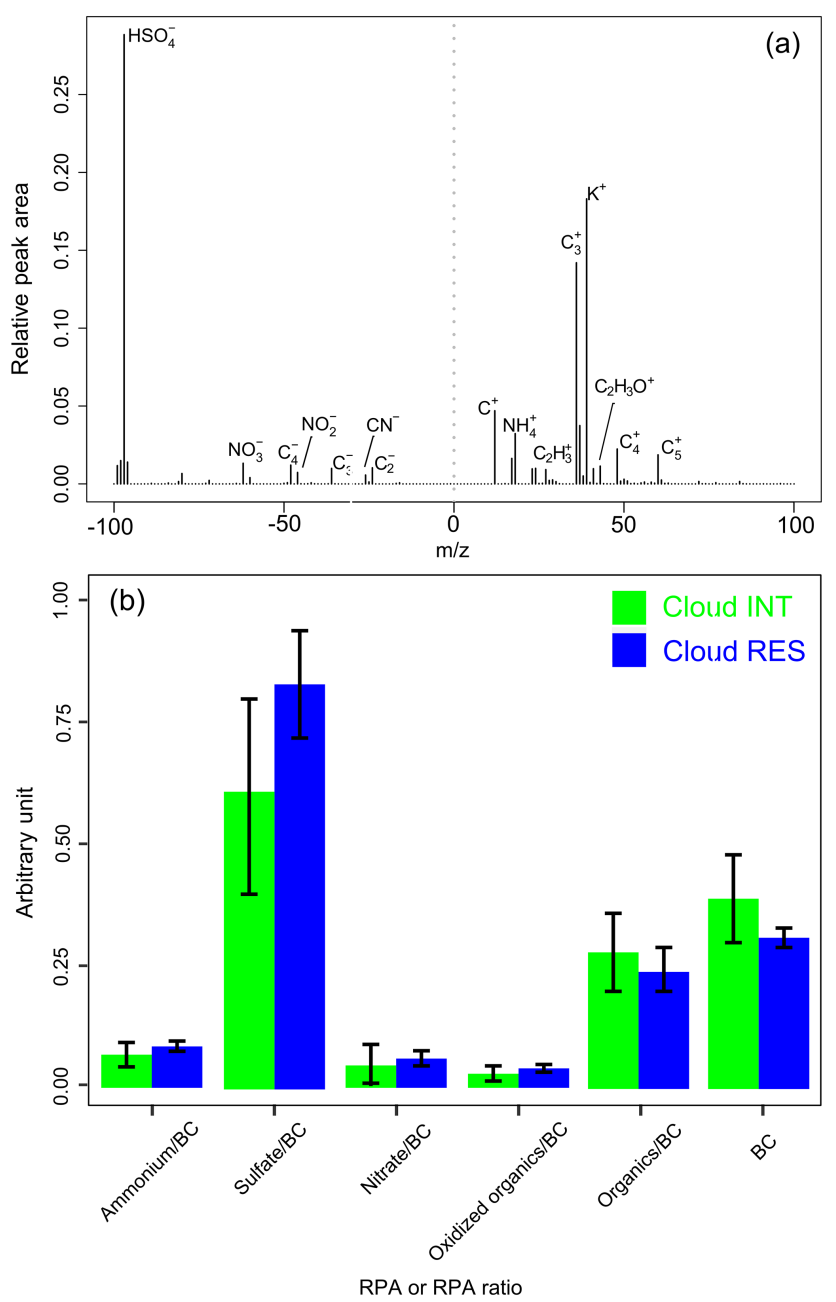

Figure 3. (a) Average mass spectrum of the cloud RES BCcontaining particles and (b) the relative peak area (RPA) ratios of ammonium, sulfate, nitrate, oxidized organic markers, and other organic markers (i.e., $m / z, 27\left[\mathrm{C}_{2} \mathrm{H}_{3}\right]^{+},-26[\mathrm{CN}]^{-}, 37\left[\mathrm{C}_{3} \mathrm{H}\right]^{+}$, $50\left[\mathrm{C}_{4} \mathrm{H}_{2}\right]^{+}, 51\left[\mathrm{C}_{4} \mathrm{H}_{3}\right]^{+}, 61\left[\mathrm{C}_{5} \mathrm{H}\right]^{+}$, and $63\left[\mathrm{C}_{5} \mathrm{H}_{3}\right]^{+}$) to BC (carbon ion clusters $\left.\left(\mathrm{C}_{n}^{ \pm}, n \leq 5\right)\right)$ and the RPAs of $\mathrm{BC}$ for the cloud RES and INT particles, respectively. Error bars represent the SD in the hourly average RPA or the RPA ratios within a $95 \%$ confidence interval.

$\left(\sim 50 \mathrm{ng} \mathrm{m}^{-3}\right)$ observed during the other two events. Similarly, the number fraction of the BC-containing particles in the cloud RES particles during cloud II $(\sim 60 \%)$ was higher than those during the other two cloud events $(<30 \%)$. This case might provide partial evidence for the influence of anthropogenic emissions and atmospheric transport on the formation of clouds at the remote high-altitude site in southern China.

\subsection{Mixing state of $\mathrm{BC}$ for cloud-free, residual, and interstitial particles}

The dominant ion peaks for the cloud-free, cloud RES, and cloud INT BC-containing particles were those of carbon cluster ions $\left(\mathrm{C}_{\mathrm{n}}^{ \pm}, n=1,2,3, \ldots\right)$, OC fragments $(\mathrm{m} / z$ $27\left[\mathrm{C}_{2} \mathrm{H}_{3}\right]^{+},-26[\mathrm{CN}]^{-}, 37\left[\mathrm{C}_{3} \mathrm{H}\right]^{+}$, and $43\left[\mathrm{C}_{2} \mathrm{H}_{3} \mathrm{O}\right]^{+}$), and secondary inorganic species, such as sulfate $\left(-97\left[\mathrm{HSO}_{4}\right]^{-}\right)$, nitrate $\left(-62\left[\mathrm{NO}_{3}\right]^{-}\right.$and $\left.-46\left[\mathrm{NO}_{2}\right]^{-}\right)$, and ammonium $\left(18\left[\mathrm{NH}_{4}\right]^{+}\right)$(Zhang et al., 2014). The cloud-free BCcontaining particles were internally mixed to a great extent with detectable sulfate ( $97 \%$ by number), nitrate $(50 \%)$, oxidized organics $\left(43\left[\mathrm{C}_{2} \mathrm{H}_{3} \mathrm{O}\right]^{+}, 72 \%\right)$, and/or ammonium (79\%), as presented in Fig. S3. A similar mixing state of the BC-containing particles has been observed at both urban and mountain sites (Moffet and Prather, 2009; Li et al., 2011b; Cahill et al., 2012). The overwhelming association of $\mathrm{BC}$ with sulfate strongly indicates a substantial influence of anthropogenic emissions of sulfate precursors (e.g., $\mathrm{SO}_{2}$ ) on the aging of BC (Huang and Yu, 2008; Khalizov et al., 2009; Guo et al., 2012; Peng et al., 2016), which directly enhances the incorporation of $\mathrm{BC}$ into clouds as discussed in section 3.2. Compared to the BC-containing particles at urban and suburban sites that are situated close to emission sources, the relative amounts of sulfate and ammonium substantially increased for those at the mountain site, as shown in Fig. S4. The relative peak area (RPA) of each $m / z$ relative to the sum of the peak areas in a mass spectrum was applied herein to represent the relative amount of a species in a particle (e.g., Jeong et al., 2011; Xing et al., 2011; Healy et al., 2013). The enhancement of sulfate in the atmosphere above southern China is reasonable since sulfate accounts for the largest portion of the compositions in this region and should be mainly associated with ammonium (Zhang et al., 2013). As expected, the temporal variations of the RPAs were significantly correlated $(p<0.01)$ between ammonium and sulfate (Fig. S5). These species were generally regarded as secondary components, and thus such high fractions of the internal mixing state and the enhancement of ammonium and sulfate at the high-altitude site demonstrate a highly aged state of the BC-containing particles.

As shown in Fig. 3, the secondary components were enhanced in the cloud RES BC-containing particles relative to the cloud INT BC-containing particles. The enhancement was more obvious for sulfate rather than for ammonium, oxidized organics, or nitrate. The enhancement of sulfate in cloud RES particles has been broadly observed (Kamphus et al., 2010; Zelenyuk et al., 2010; Hiranuma et al., 2011). A comparison of the size distributions of the cloud RES and cloud INT BC-containing particles (Fig. 4) further suggests that the in-cloud addition of secondary components shifted the BC-containing particles towards larger sizes, which is discussed in the following section. Overall, our observations suggest that the BC-containing particles were heavily coated at the high-altitude site and that the in-cloud production of 


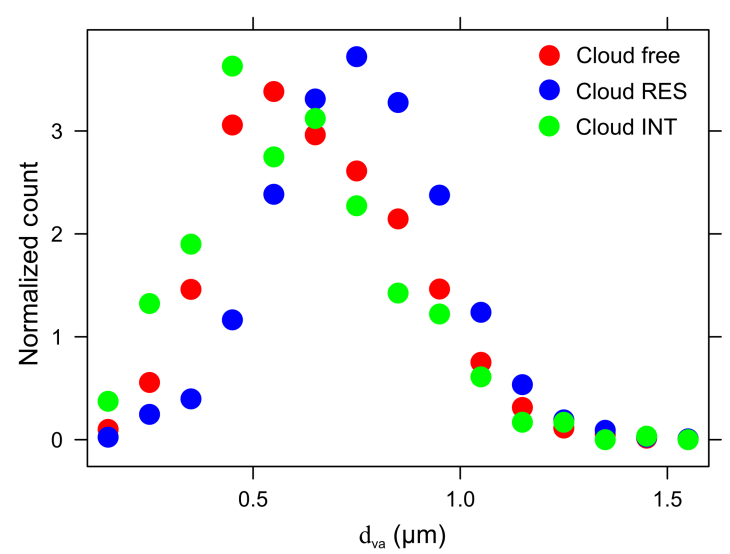

Figure 4. Normalized SPAMS particle count (to average count) over the measured size range for the cloud-free, cloud INT, and cloud RES BC-containing particles, respectively. The data were averaged throughout the sampling period.

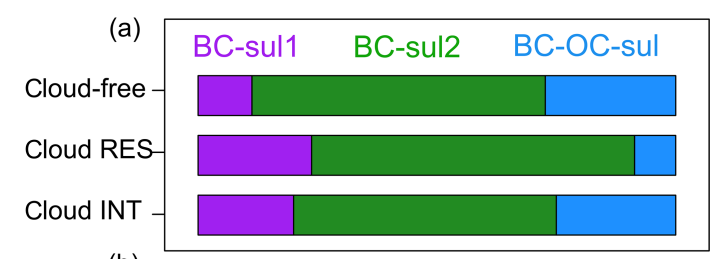

(b)

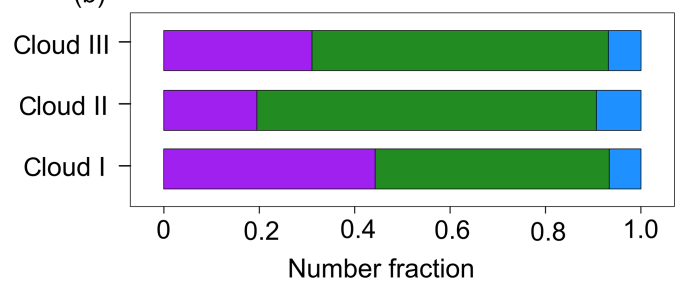

Figure 5. (a) Number fraction of each BC particle type in the cloudfree, INT, and RES BC-containing particles and (b) the number fraction of each BC particle type in the cloud RES BC-containing particles separated for the three cloud events.

coating materials (e.g., ammonium sulfate) was present. Although an abundance of BC-coated materials was also observed at Mount Soledad by a single-particle soot photometer (Schroder et al., 2015), the chemical compositions of the coated materials cannot be obtained to provide further information on the mixing state of BC. Our analysis further reflects the importance of the chemical mixing state on the cloud processing of $\mathrm{BC}$.

The role of the mixing state on the scavenging of the BC-containing particles was further investigated through a comparison of the individual particle types of the cloudfree, cloud RES, and cloud INT BC-containing particles. As shown in Fig. 5, the number fraction of BC-OC-sul $(\sim 8 \%)$ was much lower in the cloud RES than those $(\sim 25 \%)$ in the cloud-free and cloud INT BC-containing particles. Despite the different distributions of the $\mathrm{BC}$ particle types, the
BC-sul1 and BC-sul2 types were dominant, while the BCOC-sul type contributed only a limited fraction to the cloud RES BC-containing particles during each of the cloud events. Consistently, the number fraction of the BC-OC-sul particles was generally lower than 0.1 over the detected size range, which is much lower than those for the BC-sull and BCsul2 types (Fig. S6). Distinct differences in the mixing state accompanied the observations of cloud RES BC-containing particles. The cloud RES BC-containing particles with more sulfate and fewer organics were observed more frequently than those with more organics and less sulfate (Fig. 5).

\subsection{Fractions of BC incorporated into cloud droplets}

\subsubsection{Size-resolved scavenging of BC-containing particles}

The normalized number size distributions of the cloudfree, cloud RES, and cloud INT BC-containing particles are shown in Fig. 4. A representative comparison between the size distributions measured by the SPAMS and the SMPS can be found in Fig. S7. While these distributions do not represent the actual particle number size distributions due to the decreasing detection efficiencies at smaller sizes (Allen et al., 2000; Wenzel et al., 2003; Qin et al., 2006), they could reflect the importance of the particle size on the incorporation of BC-containing particles into cloud droplets (Dusek et al., 2006; Matsui, 2016). The cloud RES BC-containing particles had the largest size mode, followed by the cloud-free BC-containing particles, with the cloud INT BC-containing particles in the smallest size mode. These size distribution patterns are indicative of the preferential activation of larger particles and/or the addition of secondary species during incloud processing and are consistent with those of previous studies (Drewnick et al., 2007; Zelenyuk et al., 2010; Roth et al., 2016). As expected, the BC-containing particles were internally mixed with increasingly higher intensities of sulfate, ammonium, and oxidized organics with increasing size (Fig. S8). These results are consistent with the observations by Healy et al. (2012) and Zhang et al. (2014) insomuch that larger BC-containing particles were more thickly coated. The BC-containing particles detected by the SPAMS could track the variations of the $\mathrm{BC}$ mass concentration in the present study based on a correlation analysis of the time series of the unscaled number of BC-containing particles and the concentration of EBC (Fig. S9). A detailed discussion on the comparison of these two measurements can be found in the Supplement (Yu et al., 2010; Huang et al., 2011, 2012).

The size-resolved scavenged/activated fractions $\left(\mathrm{Nf}_{\text {scav }}\right)$ of the BC-containing particles and all the detected particles were further investigated as a function of their size (Fig. 6). The number fractions of the BC-containing particles incorporated into cloud droplets varied between 0.05 and 0.45 . The $\mathrm{Nf}_{\text {scav }}$ generally increased with an increase in the size, and those of the $\mathrm{BC}$-containing particles were scavenged to 


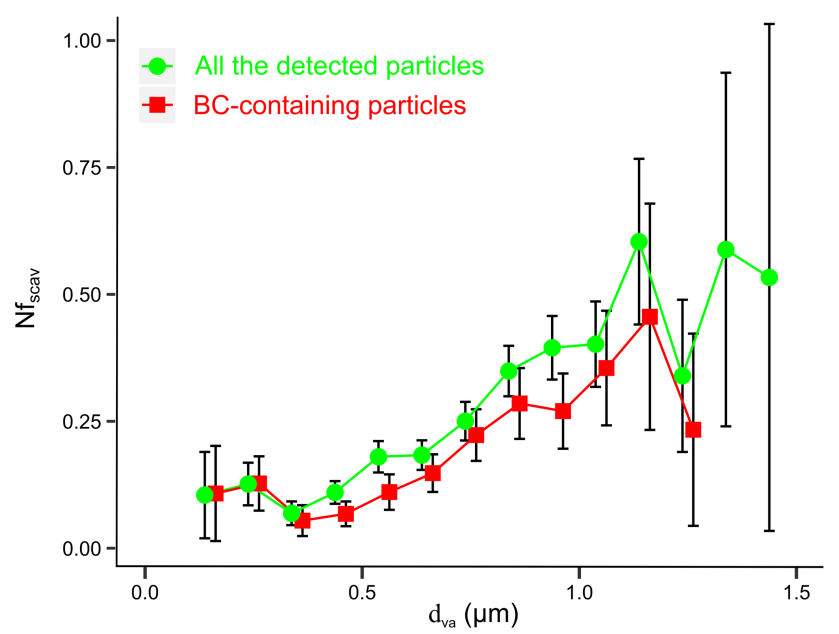

Figure 6. Size-resolved $\mathrm{Nf}_{\text {scav }}$ estimated for the BC-containing particles and all the detected particles. The $\mathrm{Nf}_{\mathrm{scav}}$ is calculated as the ratio of the average number size distribution for the cloud RES particles to the sum of the average number size distributions for the cloud RES and INT particles. Errors were estimated assuming that the particle numbers detected by the SPAMS follow a Poisson distribution.

a similar (or slightly lower) extent as those (0.07-0.6) of all the detected particles. The size-dependent scavenging of the BC-containing particles is consistent with a modeling study by Matsui (2016). This indicates that the coating materials on the BC-containing particles enhanced their ability to act as CCN (Khalizov et al., 2009; Henning et al., 2012; Roth et al., 2016), consistent with the enhanced internal mixing with secondary soluble species with an increase in the size (Fig. S8) discussed above. The increase of $\mathrm{Nf}_{\text {scav }}$ with the particle size also suggests that nucleation scavenging is the dominant mechanism for the incorporation of BC-containing particles into cloud droplets (Schroder et al., 2015). These fractions represent a rough estimate because the $\mathrm{BC}$-containing particles in the cloud RES and cloud INT particles were measured intermittently rather than simultaneously.

Relatively lower scavenging efficiency $(0.05-0.45)$ in the present study was most likely attributed to less dense clouds (with a liquid water content or LWC $<0.1 \mathrm{~g} \mathrm{~m}^{-3}$ ). Similarly, Matsui (2016) suggested that it is not correct to assume all $\mathrm{BC}$-containing particles to be $\mathrm{CCN}$-active in a cloud that has low maximum supersaturation (i.e., $0.1 \%$ ). Generally, the half activated diameter increases with decreasing LWC. Henning et al. (2002) stated that particles with $d_{\mathrm{ve}}=700 \mathrm{~nm}$ were only half activated with $\mathrm{LWC}<0.1 \mathrm{~g} \mathrm{~m}^{-3}$, in contrast, particles with $d_{\mathrm{ve}}=\sim 100 \mathrm{~nm}$ can be half activated when the LWC $>0.15 \mathrm{~g} \mathrm{~m}^{-3}$. Hammer et al. (2014) showed that only particles with a $d_{\mathrm{ve}}$ larger than $300-500 \mathrm{~nm}$ could be activated under low-LWC conditions ( $\mathrm{LWC}<0.1 \mathrm{~g} \mathrm{~m}^{-3}$ ), which is a typical condition for the formation of fog at the ground level. With an LWC of approximately $0.1 \mathrm{~g} \mathrm{~m}^{-3}$, Schroder et al. (2015) reported even lower $\mathrm{Nf}_{\text {scav }}(0.01-0.1)$ of $\mathrm{BC}$ containing particles at Mount Soledad closer to the source region in California, USA. From this perspective, the relatively higher scavenged fractions of the BC-containing particles in the present study compared to those at Mount Soledad (Schroder et al., 2015) could be mainly attributed to the longrange transport that resulted in the highly aged $\mathrm{BC}$ and possibly the higher LWC.

\subsubsection{Mass scavenging efficiency of EBC}

The concentration of EBC (5th-95th) obtained using the AE33 for the cloud-free air varied over a wide range of 57 $812 \mathrm{ng} \mathrm{m}^{-3}$ with a mean value of $418 \pm 248 \mathrm{ng} \mathrm{m}^{-3}$, which accounted for $\sim 2 \%$ of the $\mathrm{PM}_{2.5}$ on average. The average concentrations of the cloud RES and INT EBC were $84 \pm 75$, and $198 \pm 125 \mathrm{ng} \mathrm{m}^{-3}$, respectively. A relatively lower contribution of EBC to the aerosol population supports a substantial addition of secondary aerosols during transport to the high-altitude site given that EBC represents far more than $\sim 2 \%$ of the fine particles near the source regions of southern China (Lan et al., 2013; Wu et al., 2013; Zhang et al., 2013). The observed relatively lower fraction of EBC is consistent with the highly aged state of the BCcontaining particles at the high-altitude site rather than at urban and suburban sites, as discussed in Sect. 3.1. The mean concentration is much lower than those observed for urban (6000 $\mathrm{ng} \mathrm{m}^{-3}$ ) and rural (2600 $\mathrm{ng} \mathrm{m}^{-3}$ ) areas (Huang et al., 2012) in southern China. It is similar to those observed at an oceanic site $\left(540 \mathrm{ng} \mathrm{m}^{-3}\right)$ in southern China (Wu et al., 2013) and at the high-altitude Mount Rax site (430-720 $\mathrm{ng} \mathrm{m}^{-3}$ ) (Hitzenberger et al., 2001). It is several times higher than those at a marine boundary layer site $\left(70 \mathrm{ng} \mathrm{m}^{-3}\right)$ in California, USA (Schroder et al., 2015), the mid-altitude regions $\left(\sim 60 \mathrm{ng} \mathrm{m}^{-3}\right)$ of Nova Scotia, Canada (Chýlek et al., 1996), and the high alpine Jungfraujoch station $\left(50-60 \mathrm{ng} \mathrm{m}^{-3}\right)$ in Switzerland (Cozic et al., 2007). Additional detailed information on the sampling sites and $\mathrm{BC}$ concentrations can be found in Table S1 in the Supplement. These comparisons suggest that anthropogenic activities have a relatively larger impact on the concentration of EBC at the high-altitude site in the present study.

It can be seen in Fig. 1 that cloud scavenging could have a strong effect on the decreased particle concentrations (i.e., of EBC and $\mathrm{PM}_{2.5}$ ). A sharp reduction in the particle concentrations were observed at the beginning of the cloud events. The mass-scavenging efficiency of $\mathrm{BC}\left(\mathrm{Mf}_{\text {scav,EBC }}\right)$, defined as the fraction of EBC incorporated into cloud droplets relative to the total amount of EBC (Cozic et al., 2007), was evaluated as

$\mathrm{Mf}_{\text {scav }, \mathrm{EBC}}=\mathrm{EBC}_{\mathrm{RES}} /\left(\mathrm{EBC}_{\mathrm{RES}}+\mathrm{EBC}_{\mathrm{INT}}\right) \times 100 \%$.

Since the $\mathrm{EBC}_{\mathrm{RES}}$ and $\mathrm{EBC}_{\mathrm{INT}}$ were not simultaneously obtained using the $\mathrm{AE}-33$, the $\mathrm{EBC}_{\mathrm{INT}}$ measured concurrently by the AE-31 was applied in the calculation. The EBC mea- 
sured using the AE-31 is significantly correlated $\left(R^{2}=0.9\right.$, $p<0.001$ ) with and only slightly lower than that measured by the AE-33, as shown in Fig. S10. This validates the calculation in $\mathrm{R} 1$. The overall uncertainty in the $\mathrm{Mf}_{\mathrm{scav}, \mathrm{EBC}}$ is within $10 \%$, as assessed in the Supplement. The measurements of EBC and the sampling of the cloud RES particles were regarded as the main influential factors.

The $\mathrm{Mf}_{\text {scav,EBC }}$ ranged between 15 and $54 \%$ (5th-95th) with an average value of approximately $33 \%$. The $\mathrm{Mf}_{\text {scav,EBC }}$ in this study is within the range of those values (33-54\%) reported for mid-altitude (approximately $1500 \mathrm{~m}$ ) mountain sites, generally lower than those reported (45-74\%) for highaltitude (approximately $3000 \mathrm{~m}$ ) mountain sites, and higher than those reported (6-15\%) for ground sites (Cozic et al., 2007 , and references therein). The differences among the various observations are generally attributed to the water content and the sizes and mixing state of the $\mathrm{BC}$-containing particles (Cozic et al., 2007). The $\mathrm{Mf}_{\text {scav, EBC }}$ was not so different for the cloud events (Fig. S11) impacted by different air masses, which is consistent with the highly aged state of the $\mathrm{BC}$ observed in this study. These results indicate that the incorporation of $\mathrm{BC}$ into clouds was dominantly controlled by its mixing state rather than other factors (e.g., the air mass or the concentration of EBC) under low-LWC conditions (e.g., $<0.1 \mathrm{~g} \mathrm{~m}^{-3}$ ).

\section{Conclusions}

The influences of the size and mixing state on the incorporation of $\mathrm{BC}$ in clouds were investigated at a remote highaltitude mountain site in southern China. On average, the mass concentration of EBC was $418 \pm 248,84 \pm 75$, and $198 \pm$ $125 \mathrm{ng} \mathrm{m}^{-3}$ for the cloud-free, cloud RES, and cloud INT particles, respectively. The $\mathrm{BC}$ was highly aged through the predominant accumulation of sulfate during transport. BCcontaining particles were found to be scavenged in the cloud phase to a similar extent as bulk aerosols. The size-resolved scavenged fraction of BC-containing particles was estimated to be in a range of 0.05-0.45; it increased with an increase in the size and was mainly controlled by the mixing state with secondary soluble species. These data are restricted to particles in the size range of $0.1-1.6 \mu \mathrm{m}$, and thus particles with sizes smaller than $0.1 \mu \mathrm{m}$ that might serve as $\mathrm{CCN}$ are beyond the scope of this study. The mass-scavenging efficiency of $\mathrm{BC}$ varied between 15 and $54 \%$ and was independent of the air mass. This paper provides the first direct evidence on the substantial contribution of BC-containing particles to cloud droplet residual particles in the free troposphere of southern China. Our results also suggest that it might be appropriate to consider BC-containing particles as a highly aged state in the free troposphere in future studies. The data are also useful for constraining models used for predicting $\mathrm{BC}$ concentrations in the free troposphere.
Data availability. Data are available on request from Xinhui Bi (bixh@gig.ac.cn).

\section{The Supplement related to this article is available online at https://doi.org/10.5194/acp-17-14975-2017- supplement.}

Competing interests. The authors declare that they have no conflict of interest.

Acknowledgements. This work was supported by the National Key Research and Development Program of China (2017YFC0210104), the National Natural Science Foundation of China (nos. 91544101 and 41775124), the Foundation for Leading Talents of the Guangdong Province Government, and the State Key Laboratory of Organic Geochemistry (SKLOGA201603A and SKLOGC201604). This is contribution no. IS-2481 from GIGCAS.

Edited by: Armin Sorooshian

Reviewed by: two anonymous referees

\section{References}

Allen, J. O., Fergenson, D. P., Gard, E. E., Hughes, L. S., Morrical, B. D., Kleeman, M. J., Gross, D. S., Galli, M. E., Prather, K. A., and Cass, G. R.: Particle detection efficiencies of aerosol time of flight mass spectrometers under ambient sampling conditions, Environ. Sci. Technol., 34, 211-217, 2000.

Andreae, M. O. and Rosenfeld, D.: Aerosol-cloudprecipitation interactions. Part 1. The nature and sources of cloud-active aerosols, Earth-Sci. Rev., 89, 13-41, https://doi.org/10.1016/j.earscirev.2008.03.001, 2008.

Arnott, W. P., Hamasha, K., Moosmuller, H., Sheridan, P. J., and Ogren, J. A.: Towards aerosol light-absorption measurements with a 7-wavelength Aethalometer: Evaluation with a photoacoustic instrument and 3-wavelength nephelometer, Aerosol Sci. Tech., 39, 17-29, https://doi.org/10.1080/027868290901972, 2005.

Atkinson, J. D., Murray, B. J., Woodhouse, M. T., Whale, T. F., Baustian, K. J., Carslaw, K. S., Dobbie, S., O’Sullivan, D., and Malkin, T. L.: The importance of feldspar for ice nucleation by mineral dust in mixed-phase clouds, Nature, 498, 355-358, https://doi.org/10.1038/nature12278, 2013.

Backman, J., Schmeisser, L., Virkkula, A., Ogren, J. A., Asmi, E., Starkweather, S., Sharma, S., Eleftheriadis, K., Uttal, T., Jefferson, A., Bergin, M., and Makshtas, A.: On Aethalometer measurement uncertainties and multiple scattering enhancement in the Arctic, Atmos. Meas. Tech. Discuss., https://doi.org/10.5194/amt-2016-294, in review, 2016.

Baustian, K. J., Cziczo, D. J., Wise, M. E., Pratt, K. A., Kulkarni, G., Hallar, A. G., and Tolbert, M. A.: Importance of aerosol composition, mixing state, and morphology for heterogeneous ice nucleation: A combined field and laboratory approach, J. Geophys. Res.-Atmos., 117, 2240-2260, https://doi.org/10.1029/2011jd016784, 2012. 
Bi, X. H., Lin, Q. H., Peng, L., Zhang, G. H., Wang, X. M., Brechtel, F. J., Chen, D. H., Li, M., Peng, P. A., Sheng, G. Y., and Zhou, Z.: In situ detection of the chemistry of individual fog droplet residues in the Pearl River Delta region, China, J. Geophys. Res.-Atmos., 121, 9105-9116, https://doi.org/10.1002/2016JD024886, 2016.

Bond, T. C., Doherty, S. J., Fahey, D. W., Forster, P. M., Berntsen, T., DeAngelo, B. J., Flanner, M. G., Ghan, S., Karcher, B., Koch, D., Kinne, S., Kondo, Y., Quinn, P. K., Sarofim, M. C., Schultz, M. G., Schulz, M., Venkataraman, C., Zhang, H., Zhang, S., Bellouin, N., Guttikunda, S. K., Hopke, P. K., Jacobson, M. Z., Kaiser, J. W., Klimont, Z., Lohmann, U., Schwarz, J. P., Shindell, D., Storelvmo, T., Warren, S. G., and Zender, C. S.: Bounding the role of black carbon in the climate system: A scientific assessment, J. Geophys. Res.Atmos., 118, 5380-5552, https://doi.org/10.1002/Jgrd.50171, 2013.

Cahill, J. F., Suski, K., Seinfeld, J. H., Zaveri, R. A., and Prather, K. A.: The mixing state of carbonaceous aerosol particles in northern and southern California measured during CARES and CalNex 2010, Atmos. Chem. Phys., 12, 10989-11002, https://doi.org/10.5194/acp-12-10989-2012, 2012.

Chýlek, P., Banic, C. M., Johnson, B., Damiano, P. A., Isaac, G. A., Leaitch, W. R., Liu, P. S. K., Boudala, F. S., Winter, B., and Ngo, D.: Black carbon: Atmospheric concentrations and cloud water content measurements over southern Nova Scotia, J. Geophys. Res.-Atmos., 101, 29105-29110, https://doi.org/10.1029/95JD03433, 1996.

Ching, J., Riemer, N., and West, M.: Impacts of black carbon mixing state on black carbon nucleation scavenging: Insights from a particle-resolved model, J. Geophys. Res.-Atmos., 117, 1-21, 2012.

Cozic, J., Verheggen, B., Mertes, S., Connolly, P., Bower, K., Petzold, A., Baltensperger, U., and Weingartner, E.: Scavenging of black carbon in mixed phase clouds at the high alpine site Jungfraujoch, Atmos. Chem. Phys., 7, 1797-1807, https://doi.org/10.5194/acp-7-1797-2007, 2007.

Cubison, M. J., Ervens, B., Feingold, G., Docherty, K. S., Ulbrich, I. M., Shields, L., Prather, K., Hering, S., and Jimenez, J. L.: The influence of chemical composition and mixing state of Los Angeles urban aerosol on CCN number and cloud properties, Atmos. Chem. Phys., 8, 5649-5667, https://doi.org/10.5194/acp-8-56492008, 2008.

DeCarlo, P. F., Slowik, J. G., Worsnop, D. R., Davidovits, P., and Jimenez, J. L.: Particle morphology and density characterization by combined mobility and aerodynamic diameter measurements. Part 1: Theory, Aerosol Sci. Tech., 38, 1185-1205, https://doi.org/10.1080/027868290903907, 2004.

Drewnick, F., Schneider, J., Hings, S. S., Hock, N., Noone, K., Targino, A., Weimer, S., and Borrmann, S.: Measurement of ambient, interstitial, and residual aerosol particles on a mountaintop site in central Sweden using an aerosol mass spectrometer and a CVI, J. Atmos. Chem., 56, 1-20, https://doi.org/10.1007/s10874-006-9036-8, 2007.

Drinovec, L., Močnik, G., Zotter, P., Prévôt, A. S. H., Ruckstuhl, C., Coz, E., Rupakheti, M., Sciare, J., Müller, T., Wiedensohler, A., and Hansen, A. D. A.: The "dual-spot" Aethalometer: an improved measurement of aerosol black carbon with real- time loading compensation, Atmos. Meas. Tech., 8, 1965-1979, https://doi.org/10.5194/amt-8-1965-2015, 2015.

Dusek, U., Frank, G. P., Hildebrandt, L., Curtius, J., Schneider, J., Walter, S., Chand, D., Drewnick, F., Hings, S., Jung, D., Borrmann, S., and Andreae, M. O.: Size matters more than chemistry for cloud-nucleating ability of aerosol particles, Science, 312, 1375-1378, https://doi.org/10.1126/science.1125261, 2006.

Furutani, H., Dall'osto, M., Roberts, G. C., and Prather, K. A.: Assessment of the relative importance of atmospheric aging on CCN activity derived from field observations, Atmos. Environ., 42, 3130-3142, https://doi.org/10.1016/j.atmosenv.2007.09.024, 2008.

Guo, J., Wang, Y., Shen, X. H., Wang, Z., Lee, T., Wang, X. F., Li, P. H., Sun, M. H., Collett, J. L., Wang, W. X., and Wang, T.: Characterization of cloud water chemistry at Mount Tai, China: Seasonal variation, anthropogenic impact, and cloud processing, Atmos. Environ., 60, 467-476, https://doi.org/10.1016/j.atmosenv.2012.07.016, 2012.

Hammer, E., Gysel, M., Roberts, G. C., Elias, T., Hofer, J., Hoyle, C. R., Bukowiecki, N., Dupont, J.-C., Burnet, F., Baltensperger, U., and Weingartner, E.: Size-dependent particle activation properties in fog during the ParisFog 2012/13 field campaign, Atmos. Chem. Phys., 14, 10517-10533, https://doi.org/10.5194/acp-1410517-2014, 2014.

Hayden, K. L., Macdonald, A. M., Gong, W., Toom-Sauntry, D., Anlauf, K. G., Leithead, A., Li, S. M., Leaitch, W. R., and Noone, K.: Cloud processing of nitrate, J. Geophys. Res.-Atmos., 113, 1-18, https://doi.org/10.1029/2007jd009732, 2008

Healy, R. M., Sciare, J., Poulain, L., Kamili, K., Merkel, M., Müller, T., Wiedensohler, A., Eckhardt, S., Stohl, A., Sarda-Estève, R., McGillicuddy, E., O’Connor, I. P., Sodeau, J. R., and Wenger, J. C.: Sources and mixing state of size-resolved elemental carbon particles in a European megacity: Paris, Atmos. Chem. Phys., 12, 1681-1700, https://doi.org/10.5194/acp-12-1681-2012, 2012.

Healy, R. M., Sciare, J., Poulain, L., Crippa, M., Wiedensohler, A., Prévôt, A. S. H., Baltensperger, U., Sarda-Estève, R., McGuire, M. L., Jeong, C.-H., McGillicuddy, E., O’Connor, I. P., Sodeau, J. R., Evans, G. J., and Wenger, J. C.: Quantitative determination of carbonaceous particle mixing state in Paris using single-particle mass spectrometer and aerosol mass spectrometer measurements, Atmos. Chem. Phys., 13, 9479-9496, https://doi.org/10.5194/acp-13-9479-2013, 2013.

Heintzenberg, J., Cereceda-Balic, F., Vidal, V., and Leck, C.: Scavenging of black carbon in Chilean coastal fogs, Sci. Total. Environ., 541, 341-347, 2016.

Henning, S., Weingartner, E., Schmidt, S., Wendisch, M., Gaggeler, H. W., and Baltensperger, U.: Size-dependent aerosol activation at the high-alpine site Jungfraujoch (3580 ma.s.1.), Tellus B, 54, 82-95, 2002.

Henning, S., Ziese, M., Kiselev, A., Saathoff, H., Möhler, O., Mentel, T. F., Buchholz, A., Spindler, C., Michaud, V., Monier, M., Sellegri, K., and Stratmann, F.: Hygroscopic growth and droplet activation of soot particles: uncoated, succinic or sulfuric acid coated, Atmos. Chem. Phys., 12, 4525-4537, https://doi.org/10.5194/acp-12-4525-2012, 2012.

Herrmann, H., Schaefer, T., Tilgner, A., Styler, S. A., Weller, C., Teich, M., and Otto, T.: Tropospheric aqueousphase chemistry: kinetics, mechanisms, and its coupling 
to a changing gas phase, Chem. Rev., 115, 4259-4334, https://doi.org/10.1021/cr500447k, 2015.

Hiranuma, N., Kohn, M., Pekour, M. S., Nelson, D. A., Shilling, J. E., and Cziczo, D. J.: Droplet activation, separation, and compositional analysis: laboratory studies and atmospheric measurements, Atmos. Meas. Tech., 4, 2333-2343, https://doi.org/10.5194/amt-4-2333-2011, 2011.

Hitzenberger, R., Berner, A., Glebl, H., Drobesch, K., KasperGiebl, A., Loeflund, M., Urban, H., and Puxbaum, H.: Black carbon $(\mathrm{BC})$ in alpine aerosols and cloud water - concentrations and scavenging efficiencies, Atmos. Environ., 35, 5135-5141, 2001.

Hu, M., Peng, J. F., Sun, K., Yue, D. L., Guo, S., Wiedensohler, A., and $\mathrm{Wu}, \mathrm{Z}$. J.: Estimation of size-resolved ambient particle density based on the measurement of aerosol number, mass, and chemical size distributions in the winter in Beijing, Environ. Sci. Technol., 46, 9941-9947, https://doi.org/10.1021/Es204073t, 2012.

Huang, X.-F. and Yu, J. Z.: Size distributions of elemental carbon in the atmosphere of a coastal urban area in South China: characteristics, evolution processes, and implications for the mixing state, Atmos. Chem. Phys., 8, 5843-5853, https://doi.org/10.5194/acp8-5843-2008, 2008.

Huang, X. F., Gao, R. S., Schwarz, J. P., He, L. Y., Fahey, D. W., Watts, L. A., McComiskey, A., Cooper, O. R., Sun, T. L., Zeng, L. W., Hu, M., and Zhang, Y. H.: Black carbon measurements in the Pearl River Delta region of China, J. Geophys. Res.Atmos., 116, 445-451, https://doi.org/10.1029/2010jd014933, 2011.

Huang, X. F., Sun, T. L., Zeng, L. W., Yu, G. H., and Luan, S. J.: Black carbon aerosol characterization in a coastal city in South China using a single particle soot photometer, Atmos. Environ., 51, 21-28, https://doi.org/10.1016/j.atmosenv.2012.01.056, 2012.

Jeong, C.-H., McGuire, M. L., Godri, K. J., Slowik, J. G., Rehbein, P. J. G., and Evans, G. J.: Quantification of aerosol chemical composition using continuous single particle measurements, Atmos. Chem. Phys., 11, 7027-7044, https://doi.org/10.5194/acp11-7027-2011, 2011.

Kammermann, L., Gysel, M., Weingartner, E., Herich, H., Cziczo, D. J., Holst, T., Svenningsson, B., Arneth, A., and Baltensperger, U.: Subarctic atmospheric aerosol composition: 3. Measured and modeled properties of cloud condensation nuclei, J. Geophys. Res.-Atmos., 115, 288-303, https://doi.org/10.1029/2009jd012447, 2010.

Kamphus, M., Ettner-Mahl, M., Klimach, T., Drewnick, F., Keller, L., Cziczo, D. J., Mertes, S., Borrmann, S., and Curtius, J.: Chemical composition of ambient aerosol, ice residues and cloud droplet residues in mixed-phase clouds: single particle analysis during the Cloud and Aerosol Characterization Experiment (CLACE 6), Atmos. Chem. Phys., 10, 8077-8095, https://doi.org/10.5194/acp-10-8077-2010, 2010.

Khalizov, A. F., Zhang, R. Y., Zhang, D., Xue, H. X., Pagels, J., and McMurry, P. H.: Formation of highly hygroscopic soot aerosols upon internal mixing with sulfuric acid vapor, J. Geophys. Res.Atmos., 114, 730-734, https://doi.org/10.1029/2008jd010595, 2009.

Lambe, A. T., Ahern, A. T., Wright, J. P., Croasdale, D. R., Davidovits, P., and Onasch, T. B.: Oxidative aging and cloud conden- sation nuclei activation of laboratory combustion soot, J. Aerosol Sci., 79, 31-39, 2015.

Lan, Z. J., Huang, X. F., Yu, K. Y., Sun, T. L., Zeng, L. W., and $\mathrm{Hu}, \mathrm{M}$.: Light absorption of black carbon aerosol and its enhancement by mixing state in an urban atmosphere in South China, Atmos. Environ., 69, 118-123, https://doi.org/10.1016/j.atmosenv.2012.12.009, 2013.

Li, L., Huang, Z. X., Dong, J. G., Li, M., Gao, W., Nian, H. Q., Fu, Z., Zhang, G. H., Bi, X. H., Cheng, P., and Zhou, Z.: Real time bipolar time-of-flight mass spectrometer for analyzing single aerosol particles, Int. J. Mass. Spectrom., 303, 118-124, https://doi.org/10.1016/j.ijms.2011.01.017, 2011.

Li, W. J., Li, P. R., Sun, G. D., Zhou, S. Z., Yuan, Q., and Wang, W. X.: Cloud residues and interstitial aerosols from non-precipitating clouds over an industrial and urban area in northern China, Atmos. Environ., 45, 2488-2495, https://doi.org/10.1016/j.atmosenv.2011.02.044, 2011 a.

Li, W. J., Zhou, S. Z., Wang, X. F., Xu, Z., Yuan, C., Yu, Y. C., Zhang, Q. Z., and Wang, W. X.: Integrated evaluation of aerosols from regional brown hazes over northern China in winter: Concentrations, sources, transformation, and mixing states, J. Geophys. Res.-Atmos., 116, D09301, https://doi.org/10.1029/2010jd015099, 2011b.

Lin, Q., Zhang, G., Peng, L., Bi, X., Wang, X., Brechtel, F. J., Li, M., Chen, D., Peng, P., Sheng, G., and Zhou, Z.: In situ chemical composition measurement of individual cloud residue particles at a mountain site, southern China, Atmos. Chem. Phys., 17, 8473-8488, https://doi.org/10.5194/acp-17-8473-2017, 2017.

Matsui, H.: Black carbon simulations using a size- and mixingstate-resolved three-dimensional model: 2. Aging timescale and its impact over East Asia, J. Geophys. Res.-Atmos., 121, 18081821, https://doi.org/10.1002/2015jd023999, 2016.

McFiggans, G., Artaxo, P., Baltensperger, U., Coe, H., Facchini, M. C., Feingold, G., Fuzzi, S., Gysel, M., Laaksonen, A., Lohmann, U., Mentel, T. F., Murphy, D. M., O’Dowd, C. D., Snider, J. R., and Weingartner, E.: The effect of physical and chemical aerosol properties on warm cloud droplet activation, Atmos. Chem. Phys., 6, 2593-2649, https://doi.org/10.5194/acp-6-25932006, 2006.

Moffet, R. C. and Prather, K. A.: In-situ measurements of the mixing state and optical properties of soot with implications for radiative forcing estimates, P. Natl. Acad. Sci. USA, 106, 11872 11877, https://doi.org/10.1073/pnas.0900040106, 2009.

Peng, J. F., Hu, M., Guo, S., Du, Z. F., Zheng, J., Shang, D. J., Zamora, M. L., Zeng, L. M., Shao, M., Wu, Y. S., Zheng, J., Wang, Y., Glen, C. R., Collins, D. R., Molina, M. J., and Zhang, R. Y.: Markedly enhanced absorption and direct radiative forcing of black carbon under polluted urban environments, P. Natl. Acad. Sci. USA, 113, 4266-4271, https://doi.org/10.1073/pnas.1602310113, 2016.

Petzold, A., Ogren, J. A., Fiebig, M., Laj, P., Li, S.-M., Baltensperger, U., Holzer-Popp, T., Kinne, S., Pappalardo, G., Sugimoto, N., Wehrli, C., Wiedensohler, A., and Zhang, X.-Y.: Recommendations for reporting "black carbon" measurements, Atmos. Chem. Phys., 13, 8365-8379, https://doi.org/10.5194/acp13-8365-2013, 2013.

Qin, X. Y., Bhave, P. V., and Prather, K. A.: Comparison of two methods for obtaining quantitative mass concentrations from aerosol time-of-flight mass spectrometry measurements, Anal. 
Chem., 78, 6169-6178, https://doi.org/10.1021/ac060395q, 2006.

Roth, A., Schneider, J., Klimach, T., Mertes, S., van Pinxteren, D., Herrmann, H., and Borrmann, S.: Aerosol properties, source identification, and cloud processing in orographic clouds measured by single particle mass spectrometry on a central European mountain site during HCCT-2010, Atmos. Chem. Phys., 16, 505524, https://doi.org/10.5194/acp-16-505-2016, 2016.

Schroder, J. C., Hanna, S. J., Modini, R. L., Corrigan, A. L., Kreidenwies, S. M., Macdonald, A. M., Noone, K. J., Russell, L. M., Leaitch, W. R., and Bertram, A. K.: Size-resolved observations of refractory black carbon particles in cloud droplets at a marine boundary layer site, Atmos. Chem. Phys., 15, 1367-1383, https://doi.org/10.5194/acp-15-1367-2015, 2015.

Sellegri, K., Laj, P., Dupuy, R., Legrand, M., Preunkert, S., and Putaud, J. P.: Size-dependent scavenging efficiencies of multicomponent atmospheric aerosols in clouds, J. Geophys. Res.Atmos., 108, 651-663, 2003.

Shingler, T., Dey, S., Sorooshian, A., Brechtel, F. J., Wang, Z., Metcalf, A., Coggon, M., Mülmenstädt, J., Russell, L. M., Jonsson, H. H., and Seinfeld, J. H.: Characterisation and airborne deployment of a new counterflow virtual impactor inlet, Atmos. Meas. Tech., 5, 1259-1269, https://doi.org/10.5194/amt-5-1259-2012, 2012.

Song, X. H., Hopke, P. K., Fergenson, D. P., and Prather, K. A.: Classification of single particles analyzed by ATOFMS using an artificial neural network, ART-2A, Anal. Chem., 71, 860-865, 1999.

Sorooshian, A., Wang, Z., Coggon, M. M., Jonsson, H. H., and Ervens, B.: Observations of sharp oxalate reductions in stratocumulus clouds at variable altitudes: organic acid and metal measurements during the 2011 E-PEACE Campaign, Environ. Sci. Technol., 47, 7747-7756, https://doi.org/10.1021/es4012383, 2013.

Straub, D. J., Hutchings, J. W., and Herckes, P.: Measurements of fog composition at a rural site, Atmos. Environ., 47, 195-205, https://doi.org/10.1016/j.atmosenv.2011.11.014, 2012.

van Pinxteren, D., Fomba, K. W., Mertes, S., Müller, K., Spindler, G., Schneider, J., Lee, T., Collett, J. L., and Herrmann, H.: Cloud water composition during HCCT-2010: Scavenging efficiencies, solute concentrations, and droplet size dependence of inorganic ions and dissolved organic carbon, Atmos. Chem. Phys., 16, 3185-3205, https://doi.org/10.5194/acp-16-3185-2016, 2016.

Wang, Z., Wang, T., Guo, J., Gao, R., Xue, L. K., Zhang, J. M., Zhou, Y., Zhou, X. H., Zhang, Q. Z., and Wang, W. X.: Formation of secondary organic carbon and cloud impact on carbonaceous aerosols at Mount Tai, North China, Atmos. Environ., 46, 516527, https://doi.org/10.1016/j.atmosenv.2011.08.019, 2012.

Weingartner, E., Saathoff, H., Schnaiter, M., Streit, N., Bitnar, B., and Baltensperger, U.: Absorption of light by soot particles: determination of the absorption coefficient by means of aethalometers, J. Aerosol Sci., 34, 1445-1463, https://doi.org/10.1016/S0021-8502(03)00359-8, 2003.

Wenzel, R. J., Liu, D. Y., Edgerton, E. S., and Prather, K. A.: Aerosol time-of-flight mass spectrometry during the Atlanta Supersite Experiment: 2. Scaling procedures, J. Geophys. Res.Atmos., 108, 447-457, https://doi.org/10.1029/2001jd001563, 2003.
Wu, D., Wu, C., Liao, B., Chen, H., Wu, M., Li, F., Tan, H., Deng, T., Li, H., Jiang, D., and Yu, J. Z.: Black carbon over the South China Sea and in various continental locations in South China, Atmos. Chem. Phys., 13, 12257-12270, https://doi.org/10.5194/acp-13-12257-2013, 2013.

Xing, J. H., Takahashi, K., Yabushita, A., Kinugawa, T., Nakayama, T., Matsumi, Y., Tonokura, K., Takami, A., Imamura, T., Sato, K., Kawasaki, M., Hikida, T., and Shimono, A.: Characterization of aerosol particles in the Tokyo Metropolitan Area using two different particle mass spectrometers, Aerosol Sci. Tech., 45, 315-326, https://doi.org/10.1080/02786826.2010.533720, 2011.

Yu, H., Wu, C., Wu, D., and Yu, J. Z.: Size distributions of elemental carbon and its contribution to light extinction in urban and rural locations in the pearl river delta region, China, Atmos. Chem. Phys., 10, 5107-5119, https://doi.org/10.5194/acp10-5107-2010, 2010.

Zaveri, R. A., Barnard, J. C., Easter, R. C., Riemer, N., and West, M.: Particle-resolved simulation of aerosol size, composition, mixing state, and the associated optical and cloud condensation nuclei activation properties in an evolving urban plume, J. Geophys. Res.-Atmos., 115, 1383-1392, https://doi.org/10.1029/2009jd013616, 2010.

Zelenyuk, A., Imre, D., Earle, M., Easter, R., Korolev, A., Leaitch, R., Liu, P., Macdonald, A. M., Ovchinnikov, M., and Strapp, W.: In situ characterization of cloud condensation nuclei, interstitial, and background particles using the single particle mass spectrometer, SPLAT II, Anal. Chem., 82, 7943-7951, https://doi.org/10.1021/Ac1013892, 2010.

Zhang, G., Lin, Q., Peng, L., Yang, Y., Fu, Y., Bi, X., Li, M., Chen, D., Chen, J., Cai, Z., Wang, X., Peng, P., Sheng, G., and Zhou, Z.: Insight into the in-cloud formation of oxalate based on in situ measurement by single particle mass spectrometry, Atmos. Chem. Phys., 17, 13891-13901, https://doi.org/10.5194/acp-1713891-2017, 2017.

Zhang, G. H., Bi, X. H., Chan, L. Y., Li, L., Wang, X. M., Feng, J. L., Sheng, G. Y., Fu, J. M., Li, M., and Zhou, Z.: Enhanced trimethylamine-containing particles during fog events detected by single particle aerosol mass spectrometry in urban Guangzhou, China, Atmos. Environ., 55, 121-126, https://doi.org/10.1016/j.atmosenv.2012.03.038, 2012.

Zhang, G. H., Bi, X. H., Chan, L. Y., Wang, X. M., Sheng, G. Y., and Fu, J. M.: Size-segregated chemical characteristics of aerosol during haze in an urban area of the Pearl River Delta region, China, Urban Climate, 4, 74-84, https://doi.org/10.1016/j.uclim.2013.05.002, 2013.

Zhang, G. H., Bi, X. H., He, J. J., Chen, D. H., Chan, L. Y., Xie, G. W., Wang, X. M., Sheng, G. Y., Fu, J. M., and Zhou, Z.: Variation of secondary coatings associated with elemental carbon by single particle analysis, Atmos. Environ., 92, 162-170, https://doi.org/10.1016/j.atmosenv.2014.04.018, 2014.

Zhou, Y., Wang, T., Gao, X. M., Xue, L. K., Wang, X. F., Wang, Z., Gao, J. A., Zhang, Q. Z., and Wang, W. X.: Continuous observations of water-soluble ions in $\mathrm{PM}_{2.5}$ at Mount Tai (1534 m a.s.1.) in central-eastern China, J. Atmos. Chem., 64, 107-127, 2009.

Zuberi, B., Johnson, K. S., Aleks, G. K., Molina, L. T., and Laskin, A.: Hydrophilic properties of aged soot, Geophys. Res. Lett., 32, 67-106, https://doi.org/10.1029/2004g1021496, 2005. 